\title{
AFFORESTATION OF ABANDONED PEAT EXTRACTION SITES WITH SCOTS PINE (PINUS SYLVESTRIS L.) AS A SOLUTION OF CLIMATE CHANGE MITIGATION
}

\author{
Evelīna Skrastina ${ }^{1},{ }^{*}$ Inga Straupe ${ }^{1}$, Andis Lazdiņ $\check{s}^{2}$ \\ ${ }^{1}$ Latvia University of Life Sciences and Technologies, Latvia \\ ${ }^{2}$ Latvian State Forest Reseach Institute 'Silava', Latvia \\ *Corresponding author’s email: inga.straupe@llu.lv
}

\begin{abstract}
On a global scale, ambitious climate change mitigation targets are set. By 2050, the European Union is expected to be climate neutral which means that the greenhouse gas (GHG) emissions will not exceed removals. This initiative is also supported by Latvia. For businesses and carbon intensive industries transition to climate neutral economy will be provided by Just Transition Fund. The direction of the peat sector towards climate neutrality will promote research and innovation as well as restoration of peat extraction sites. These are also the objectives of implementing the Just Transition Fund for investments in Latvia. Studies on management of peat soils to improve the calculation of greenhouse gas (GHG) emissions have been carried out in Latvia within LIFE REstore project. The aim of the study is to assess the impact of afforestation of abandoned peat extraction sites with Scots pine (Pinus sylvestris L.) on GHG emissions compared to retaining of the existing situation (abandoned peatlands with poorly developed vegetation). Afforestation of degraded peatlands can contribute to significant GHG reduction in wetlands - up to $20 \%$ of the net GHG emissions due to wetlands management. The most of the GHG mitigation potential is ensured by accumulation of $\mathrm{CO}_{2}$ in living biomass.
\end{abstract}

Key words: afforestation, greenhouse gas emissions, peat extraction sites, climate change.

\section{Introduction}

The role of wetlands as a carbon sink has become more important as they contribute to the greenhouse effect and climate change (Quinty \& Rochefort, 2003). The important role of peatlands as carbon sinks has been demonstrated by carbon cycle studies (Bāders, 2011). Although natural bogs emit greenhouse gases such as methane, drainage of bogs and peat extraction lead to significant increase in global warming potential and the loss of carbon sinks that have been developed over thousands of years (Quinty \& Rochefort, 2003; Kløve et al., 2017). The amount of carbon stored in peatlands is closely related to the thickness of the remaining peat layer and the degree of decomposition of the peat, as well as humification processes in the peat (Bāders, 2011). Bogs are types of ecosystem where carbon, along with nitrogen and several other elements, have accumulated as peat formed from plant litter that accumulates in these areas. In the past, bogs covered 5-6\% of the surface of continental Europe, half of the bogs in Europe are subject to various land uses, often associated with drainage (Drösler et al., 2008). In Latvia, according to the data of the Peat Fund of 1980, the total area of bogs is $6401 \mathrm{~km}^{2}$ or $9.9 \%$ of the country's territory. Peat resources play a significant role in both the conservation of biodiversity and its use in the economy (Jansons, 2016). In Latvia, peat was initially mined in quarries without draining the bogs. At the end of the 19th century and the most of the 20th century, peat was extracted in drained bogs. Today, many of these areas are already overgrown with forests or naturally revegetated. The use of peat generates GHG emissions from peat extraction in the peat extraction area and emissions from the use of peat in agriculture, such as forestry, forest plant growing, horticulture, livestock litter, and energy from peat incineration. In the category of weatlands in the GHG inventory, emissions are calculated from peat extraction areas where peat extraction takes place or has taken place (ha) and the amount of peat extracted $(t)$, distinguishing between agricultural and energy use (Cabinet of Ministers, 2020). In wetland category, changes in carbon stock are also calculated, in the areas with woody vegetation that do not meet the definition of forest land (living and non-living biomass) and GHG emissions from soils in areas renaturalized after peat extraction by purposefully restoring the original moisture regime or the areas, which were flooded. GHG emissions from wetlands in 2018 were $1708.92 \mathrm{kt} \mathrm{CO}_{2}$ eq. (Skrebele et al.,2020). It is important to reduce GHG emissions by avoiding the development of new peat deposits as much as possible, first of all, evaluating the possibility of peat extraction in historical peat extraction sites, where peat extraction no longer takes place, but recultivation is not perforemed (Cabinet of Ministers, 2020). Peat extraction no longer takes place in such areas, but these areas are not able to regenerate naturally as bogs or other ecosystem. In the cutaway peatlands, GHG emissions are even more negative in the context of GHG emissions without recultivation and the creation of new or expanded peat extraction sites (Priede \& Gancone, 2019). Evaluating the experience gained and accumulated in the peat extraction sector and literature, as well as information provided by industry specialists and experts, the types of recultivation suitable for Latvian conditions are: renaturalization, afforestation, berry plantations - blueberries and cranberries, cultivation of paludicultures - growing of bog plants for biomass production, creation of 
water reservoirs and growing of perennial grasslands (Cabinet of Ministers, 2020; Priede \& Gancone, 2019). Within the scope of the LIFE REstore project "Sustainable and responsible management and reuse of degraded peatlands in Latvia", areas affected by peat extraction have been identified with a total area of about 50 thousand hectares, of which about 15 thousand ha are peat extraction $(30 \%)$, about 17 thousand ha $(34 \%)$ peat extraction has taken place or is undergoing reclamation (natural regeneration, flooding and flooded areas, forests, grasslands or berry plantations) and approximately 18 thousand ha (36\%) are degraded areas subject to recultivation. In total, for 18 thousand ha of degraded, non-reclaimed peatland areas and the best suitable recultivation method for these areas has to be chosen (Priede \& Gancone, 2019). The purpose of reclamation is to ensure the continued full use of mining sites after the completion of mining, to prevent threats to human life and health and the environment, and to promote integration into the landscape (Cabinet of Ministers, 2020). The types of recultivation of peat extraction sites that have been determined in a general way, in accordance with the regulatory enactments in force in Latvia, are renaturalization (restoration of the environment characteristic of a bog), preparation for agricultural use (berry plantations), preparation for use in forestry, creating water bodies for recreation (Cabinet of Ministers, 2012). Forests is the environment, where significant part of the organic matter is preserved in the form of peat for a long time. By mobilizing the energy stored in the peat layer, the productivity of wood increases several times, additional amounts of $\mathrm{CO}_{2}$ are captured and accumulated in living biomass. Forests contribute to the reduction of the greenhouse effect by increasing the stock of wood, accumulating carbon and releasing the oxygen necessary for the existence of living organisms. Approximately 700,000 ha of forests out of 1.5 million ha of swampy and wet forests have been reclaimed in Latvia (Indriksons \& Palejs, 2005; Zālītis, 2006). Most of the $\mathrm{CO}_{2}$ emissions in Latvia are generated in organic soils, more than half of these emissions are formed in forest lands, but the emissions from soil due to wetland management are an important source of emissions, excluding GHG emissions from peat extraction (Priede \& Gancone, 2019). Average GHG emissions and $\mathrm{CO}_{2}$ removals depend on the climatic region and soils fertility. $\mathrm{CO}_{2}$ and $\mathrm{N}_{2} \mathrm{O}$ emissions from drained forest soils account for less than $10 \%$ of net emissions from forest stands, while $\mathrm{CO}_{2}$ sequestration in living biomass accounts for $35 \%$ of total $\mathrm{CO}_{2}$ sequestration in forest stands. According to the interpretation of the 2013 Supplement to the 2006 IPCC Guidelines, for all organic soils in Latvia the same emission factors have to be used, regardless of whether the area is drained or not, which means that in terms of emissions, forest stands with drained and naturally wet soils have the same emission factors. $\mathrm{CO}_{2}$ emissions from soil in forests on non-drained mineral soils and forests on drained organic soils are 2.6 tons of $\mathrm{CO}_{2}-\mathrm{C}$ per year, direct $\mathrm{N}_{2} \mathrm{O}$ emissions from soil are $2.8 \mathrm{~kg} \mathrm{~N}_{2} \mathrm{O}-\mathrm{N} \mathrm{ha}^{-1}$ per year (4.4 $\mathrm{kg} \mathrm{N}_{2} \mathrm{O} \mathrm{ha}{ }^{-1}$ or 1.3 tons $\mathrm{CO}_{2}$ eq.), $\mathrm{CH}_{4}$ emissions from ditches are $217 \mathrm{~kg} \mathrm{CH}_{4} \mathrm{ha}^{-1}$ per year (Lazdiņšs, 2015).

The most important measure to offset GHG emissions from deforestation is afforestation (Lazdin̄š, 2015). Forestry is an advantageous opportunity for recultivation of developed peat deposits, as it has both commercial and aesthetic values. Relatively new recultivation practice is afforestation of peat deposits; therefore, we are still looking for the most suitable tree species for afforestation, as well as the most suitable fertilizers that would ensure successful recultivation of the developed peat deposits in the long term (Bebre \& Lazdina, 2017). The most suitable tree species for afforestation of peat extraction sites are pine and birch (Liepiňš, Baders, \& Liepa, 2009). Afforestation ensures the accumulation of $\mathrm{CO}_{2}$ in living and non-living biomass, litter and soil (Progress report under..., 2017). According to studies in Finland and Sweden, $\mathrm{CO}_{2}$ emissions from afforested peat deposits average $1397 \mathrm{~g} \mathrm{~m}^{-2}$ per year (1008-1756 g $\mathrm{m}^{-2}$ per year $), \mathrm{CH}_{4}$ emissions are $-0.05 \mathrm{~g} \mathrm{~m}^{-2}$ per year $\left(-0.03-0.09 \mathrm{~g} \mathrm{~m}^{-2}\right.$ per year) and $\mathrm{N}_{2} \mathrm{O}$ emissions are 0.15 $\mathrm{g} \mathrm{m}^{-2}$ per year $\left(0.02-0.75 \mathrm{~g} \mathrm{~m}^{-2}\right.$ per year) (Mhkiranta et al., 2007; Alm et al., 2007).

The average additional growth of a tree trunk during the rotation period using improved planting material in reforestation is $43 \mathrm{~m}^{3} \mathrm{ha}^{-1}$ (Progress report under..., 2017). In addition, the sequestration of $\mathrm{CO}_{2}$ in living biomass using selected planting material in reforestation is on average $50 \mathrm{t} \mathrm{ha}^{-1}$ in forest management cycle. The direct impact of the selected material on the Latvian scale can reach 104 million tons of $\mathrm{CO}_{2}$ in 75 years or $138 \mathrm{Gg}$ of $\mathrm{CO}_{2}$ per year (Lazdiņš, 2015). Afforestation of developed peat deposits is a technically easily feasible practice and the main wood products are wood chips, pulpwood and roundwood (Makovskis et al., 2019). In sustainable forestry, $\mathrm{CO}_{2}$ sequestration is in balance with longterm forest growth, and felled timber form the forest can be seen as a substitute for natural extinction, which would otherwise be the same. Growing trees act as a carbon sequestration system, providing physical storage of carbon that was previously released into the atmosphere (Pingoud et al., 2003; Sathre \& O'Connor, 2010). In managed forests, carbon is retained in the resulting building materials and furniture, and the use of wood as a fuel saves the use of fossil fuels and thus eliminates additional $\mathrm{CO}_{2}$ emissions (Kḷaviņš \& Zalıksnis, 2016). 
Wood products have been identified as a significant source of $\mathrm{CO}_{2}$ removals, but may be affected by reduced logging or a deterioration in the structure of the timber being harvested (higher proportion of biofuels), as this carbon sink may become a significant source of $\mathrm{CO}_{2}$ emissions in the future (Lazdinš, 2015). Wood products reduce $\mathrm{CO}_{2}$ emissions because wood products are carbon sinks and can replace carbonintensive materials. Each cubic meter of wood captures $0.9 \mathrm{t}$ of $\mathrm{CO}_{2}$, which is not released into the atmosphere during the initial life cycle of wood products, as well as after the wood products are recycled and reused (Pingoud et al., 2003). Each cubic meter of wood used to replace other building materials reduces $\mathrm{CO}_{2}$ emissions to the atmosphere by an average of $1.1 \mathrm{t}$ of $\mathrm{CO}_{2}$, plus $0.9 \mathrm{t}$ of $\mathrm{CO}_{2}$ accumulated in wood, then a total of $2 \mathrm{t}$ of each cubic meter of wood (Beijere et al., 2006).

The aim of the study is to assess the impact of afforestation of abandoned peat extraction sites with Scots pine (Pinus sylvestris L.) on GHG emissions compared to retaining of the existing situation (abandoned peatlands with poorly developed vegetation).

\section{Materials and Methods}

During the LIFE REstore project "Sustainable and responsible management and re-use of degraded peatlands in Latvia" research work was carried out to replace the emission factors offered by Guidelines of GHG Inventories of Intergovermental Panel on Climate Change (IPCC) with nationally applicable emission factors and activity data. Ecosystem carbon dioxide $\left(\mathrm{CO}_{2}\right)$ exchange - measurements were taken, using transparent chamber method, which enables determination of the $\mathrm{CO}_{2}$ removals caused by photosynthetic activity of ground vegetation (Salm et al., 2012) and the opaque chamber method for determination of $\mathrm{CH}_{4}$ and $\mathrm{N}_{2} \mathrm{O}$ fluxes (Hutchinson \& Livingston, 1993). Gas samples were collected in $50 \mathrm{ml}$ glass flasks previously vacuumed in the lab. Gas analyses were done using a gas chromatography method. $\mathrm{CO}_{2}$ fluxes in transparent chamber were determined using EGM-5 analyser. Results of gas analyses were subjected to quality control, by verifying if changes of gas concentrations are linear during $60 \mathrm{~min}$. period (samples were taken 4 times with 20 min. interval at each sampling cycle using opaque chambers). Low quality data series $\left(\mathrm{R}^{2}\right.$ value of 4 measurements is below 0.95 for $\mathrm{CO}_{2}$ ) are excluded from further analysis. Litter input and fine root production was estimated using literature data (Neumann et al., 2019).

In Latvia, about 18 thousand ha of abandoned cutaway peatlands, where peat extraction has been ceased or completed, but no reclamation has been carried out, are identified within the LIFE REstore project. Afforestation with Scots pine Pinus sylvestris $\mathrm{L}$. is one of the best after-use scenarios to maximize climate change mitigation effect. For GHG emission reduction calculation nationally applicable emission factors elaborated in LIFE REstore project $\left(\mathrm{CH}_{4}, \mathrm{CO}_{2}\right.$ and $\mathrm{N}_{2} \mathrm{O}$ ) and default emission factors for temperate moist climate zone according to IPCC 2014 Wetlands supplement (dissolved organic carbon, proportion of ditches and $\mathrm{CH}_{4}$ from ditches) are used. For peat extraction site afforested with conifers, average net $\mathrm{CO}_{2}$ emissions are equal to $0.96 \mathrm{t} \mathrm{CO}_{2}-\mathrm{C} \mathrm{ha}^{-1}$ annually, dissolved organic carbon (DOC) $0.31 \mathrm{t} \mathrm{C} \mathrm{ha}^{-1}$ annually, $\mathrm{CH}_{4}$ emissions are $22.39 \mathrm{~kg} \mathrm{CH}_{4}$ ha $^{-1}$ annually, $\mathrm{CH}_{4}$ emissions from drainage ditches are $217 \mathrm{~kg} \mathrm{CH}_{4} \mathrm{ha}^{-1}$ annually and $\mathrm{N}_{2} \mathrm{O}$ emissions are $-0.05 \mathrm{~kg} \mathrm{~N}_{2} \mathrm{O}-\mathrm{N} \mathrm{ha}^{-1}$ annually. If peat extraction still continues, net emissions are equal to $1.09 \mathrm{tCO}_{2}-\mathrm{Cha}^{-1}$ annually, DOC $0.31 \mathrm{tCha}^{-1}$ annually, $\mathrm{CH}_{4}$ emissionsare $10.83 \mathrm{kgCH}_{4} \mathrm{ha}^{-1}$ annually, $\mathrm{CH} 4$ emissions from drainage ditches are $542 \mathrm{~kg} \mathrm{CH}_{4}$ ha $^{-1}$ annually and $\mathrm{N}_{2} \mathrm{O}$ emissions are $0.44 \mathrm{~kg} \mathrm{~N} \mathrm{O}_{2}-\mathrm{N} \mathrm{ha}^{-1}$ annually. In abandoned peat extraction fields that are not covered with vegetation (alternative scenario to compare impact of the afforestation scenario) $0.95 \mathrm{t} \mathrm{CO}_{2}-\mathrm{C} \mathrm{ha}^{-1}$ annually, DOC $0.31 \mathrm{t} \mathrm{C}^{-1}$ annually, $\mathrm{CH}_{4}$ emissions are $1.42 \mathrm{~kg} \mathrm{CH}_{4} \mathrm{ha}^{-1}$ annually, $\mathrm{CH}_{4}$ emissions from drainage ditches are $542 \mathrm{~kg} \mathrm{CH}_{4} \mathrm{ha}^{-1}$ and $\mathrm{N}_{2} \mathrm{O}$ emissions are $0.11 \mathrm{~kg} \mathrm{~N} 2 \mathrm{O}-\mathrm{N} \mathrm{ha}^{-1}$ annually. In abandoned peat extraction fields covered with vegetation that is not a tree stand $\mathrm{CO}_{2}$ emissions are $1.85 \mathrm{t} \mathrm{CO}_{2}-\mathrm{C} \mathrm{ha}^{-1}$ annually, DOC $0.31 \mathrm{t} \mathrm{C}^{-1}$ annually, $\mathrm{CH}_{4}$ emissions are $28.39 \mathrm{~kg} \mathrm{CH}_{4} \mathrm{ha}^{-1}$ annually, $\mathrm{CH}_{4}$ emissions from drainage ditches are $217 \mathrm{~kg} \mathrm{CH}_{4} \mathrm{ha}^{-1}$ and $\mathrm{N}_{2} \mathrm{O}$ emissions are $0.04 \mathrm{~kg} \mathrm{~N}_{2} \mathrm{O}-\mathrm{N} \mathrm{ha}^{-1}$ annually (Priede \& Gancone, 2019).

GHG emission reduction potential was estimated by comparison of soil GHG fluxes and carbon stock changes in case of afforestation of the abandoned peatlands and retaining of existing situation (abandoned peatland with poorly developed vegetation). Calculation period is 30 years to demonstrate GHG mitigation potential, which can be reached in 2050 by quick implementation of the afforestation measures in abandoned peatlands.

\section{Results and Discussion}

The GHG emission factors according to IPCC 2014 Wetlands supplement and LIFE Restore results applied in the calculation are provided in Figure 1.

In 18 thousand hectares (kha) abandoned peatlands with poorly developed vegetation, GHG emissions from soil according to IPCC 2014 Wetlands Supplement are the following, $\mathrm{CO}_{2}$ emissions from soil are 171.6 kilotonnes $(\mathrm{kt}) \mathrm{CO}_{2}$ eq. $\mathrm{yr}^{-1}$, DOC $20.5 \mathrm{kt} \mathrm{CO}_{2}$ eq. $\mathrm{yr}^{-1}, \mathrm{CH}_{4}$ emissions are $1.1 \mathrm{kt} \mathrm{CO}_{2}$ 
eq. $\mathrm{yr}^{-1}$ and $\mathrm{N}_{2} \mathrm{O}$ emissions are $23.6 \mathrm{kt} \mathrm{CO}_{2}$ eq. $\mathrm{yr}^{-1}$. Total GHG emissions from soil in case of continued abandonment of these areas are $216.8 \mathrm{kt} \mathrm{CO}_{2}$ eq. $\mathrm{yr}^{-1}$. According to the emission factors elaborated within the scope of the LIFE REstore project $\mathrm{CO}_{2}$ emissions in $18 \mathrm{kha}$ are $122.1 \mathrm{kt} \mathrm{CO}_{2}$ eq. $\mathrm{yr}^{-1}$, DOC $20.5 \mathrm{kt} \mathrm{CO}_{2}$ eq. $\mathrm{yr}^{-1}, \mathrm{CH}_{4}$ emissions are $12.8 \mathrm{kt} \mathrm{CO}_{2}$ eq. $\mathrm{yr}^{-1}$ and $\mathrm{N}_{2} \mathrm{O}$ emissions are $0.4 \mathrm{kt} \mathrm{CO}$ eq. $\mathrm{yr}^{-1}$. Total GHG emissions from soil are $155.7 \mathrm{kt} \mathrm{CO}_{2}$ eq. $\mathrm{yr}^{-1}$. Application of country specific $\mathrm{GHG}$ emissions factors reduces $\mathrm{GHG}$ emissions by $28 \%$.

If $18 \mathrm{kha}$ of abandoned peatlands are afforestated with Scots pine (Pinus sylvestris L.) GHG emissions from soil according to IPCC 2014 Wetlands supplement, $\mathrm{CO}_{2}$ emissions from soil are $171.6 \mathrm{kt} \mathrm{CO}_{2}$ eq. $\mathrm{yr}^{-1}$, DOC $20.46 \mathrm{kt} \mathrm{CO}_{2}$ eq. $\mathrm{yr}^{-1}, \mathrm{CH}_{4}$ emissions are $1.09 \mathrm{kt} \mathrm{CO}_{2}$ eq. $\mathrm{yr}^{-1}, \mathrm{CH}_{4}$ emissions from drainage ditches are $2.44 \mathrm{kt} \mathrm{CO}_{2}$ eq. $\mathrm{yr}^{-1}$ and $\mathrm{N}_{2} \mathrm{O}$ emissions are $23.60 \mathrm{kt} \mathrm{CO}_{2}$ eq. $\mathrm{yr}^{-1}$. Total GHG emissions from soil are $219.19 \mathrm{kt} \mathrm{CO}_{2}$ eq. $\mathrm{yr}^{-1}$. According to country specific emission factors in 18 thousand ha, $\mathrm{CO}_{2}$ emissions are $63.5 \mathrm{kt} \mathrm{CO}_{2}$ eq. $\mathrm{yr}^{-1}$, DOC $20.46 \mathrm{kt} \mathrm{CO}_{2}$ eq. $\mathrm{yr}^{-1}, \mathrm{CH}_{4}$ emissions are $9.82 \mathrm{kt} \mathrm{CO}_{2}$ eq. $\mathrm{yr}^{-1}, \mathrm{CH}_{4}$ emissions from drainage ditches are $2.44 \mathrm{kt} \mathrm{CO}_{2}$ eq. $\mathrm{yr}^{-1}$ and $\mathrm{N}_{2} \mathrm{O}$ emissions are $-0.40 \mathrm{kt} \mathrm{CO}_{2}$ eq. $\mathrm{yr}^{-1}$. Total GHG emissions from soil if country specific emission factors are applied, reduces to $95.47 \mathrm{kt} \mathrm{CO}_{2}$ eq. $\mathrm{yr}^{-1}$ (by $56 \%$ ). After afforestation carbon stock in living woody biomass increases to $93 \mathrm{tC} \mathrm{ha}^{-1}$, in dead wood to $4.50 \mathrm{t} \mathrm{C} \mathrm{ha}^{-1}$ in 30 years period and in ground

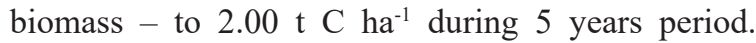
These values are used in national GHG inventory to determine impact of land use changes.

Reduction of $\mathrm{CH}_{4}$ emissions from soil following to the afforestation according to IPCC 2014 Wetlands Supplement is $0.02 \mathrm{kt} \mathrm{CO}_{2}$ eq. $\mathrm{yr}^{-1}$ and reduction of
$\mathrm{CH}_{4}$ emissions from drainage ditches $-2.44 \mathrm{kt} \mathrm{CO}_{2}$ eq. $\mathrm{yr}^{-1}$. Total GHG emission reduction from soil after afforestation is negative according to IPCC 2014 Wetlands Supplement $-2.41 \mathrm{kt} \mathrm{CO}_{2}$ eq. $\mathrm{yr}^{-1}$. According to the country specific emission factors, the reduction of $\mathrm{CO}_{2}$ emissions from soil after afforestation is $58.91 \mathrm{kt} \mathrm{CO}_{2}$ eq. $\mathrm{yr}^{-1}$, reduction of $\mathrm{CH}_{4}$ emissions is negative, including $-4.9 \mathrm{kt} \mathrm{CO}_{2}$ eq. $\mathrm{yr}^{-1}$ in forest area and $-2.44 \mathrm{kt} \mathrm{CO}_{2}$ eq. $\mathrm{yr}^{-1}$ from drainage ditches and reduction of $\mathrm{N}_{2} \mathrm{O}$ emissions is $0.77 \mathrm{kt} \mathrm{CO}_{2}$ eq. $\mathrm{yr}^{-1}$. Total GHG emission reduction from soil after afforestation, if the country specific emission factors are applied, is $60.20 \mathrm{kt} \mathrm{CO}_{2}$ eq. $\mathrm{yr}^{-1}$. The difference between the default assumptions and country specific method is $14.1 \mathrm{kt} \mathrm{CO}_{2}$ eq. $\mathrm{yr}^{-1}$. Additional reduction of GHG emissions is ensured by removals of $\mathrm{CO}_{2}$ in living and dead biomass in forest lands -9.2 tons $\mathrm{CO}_{2} \mathrm{ha}^{-1} \mathrm{yr}^{-1}$. The net GHG emission reduction does not significantly differ in case of application of the IPCC 2014 Wetlands supplement and country specific emissions factors; in 30 years period it reaches $5000 \mathrm{kt} \mathrm{CO}_{2}$ eq. (167 kt $\mathrm{CO}_{2}$ eq $\left.\mathrm{yr}^{-1}\right)$. However, the lack of difference is mainly due to significant contribution of living biomass in the estimation of the GHG emission reduction, which is the same in both scenarios (Figure 2).

In spite of similar values of $\mathrm{GHG}$ emission reduction due to afforestation, the absolute values of the emission factors elaborated by the LIFE Restore project team is about twice smaller than the default ones, which means that the GHG emissions from soil in abandoned peatlands and forest lands are significantly overestimated. Emission factors elaborated by the LIFE Restore project have also significantly smaller uncertainty range $30-80 \%$ instead of $90 \%$, and they are better adopted to country specific activity data.

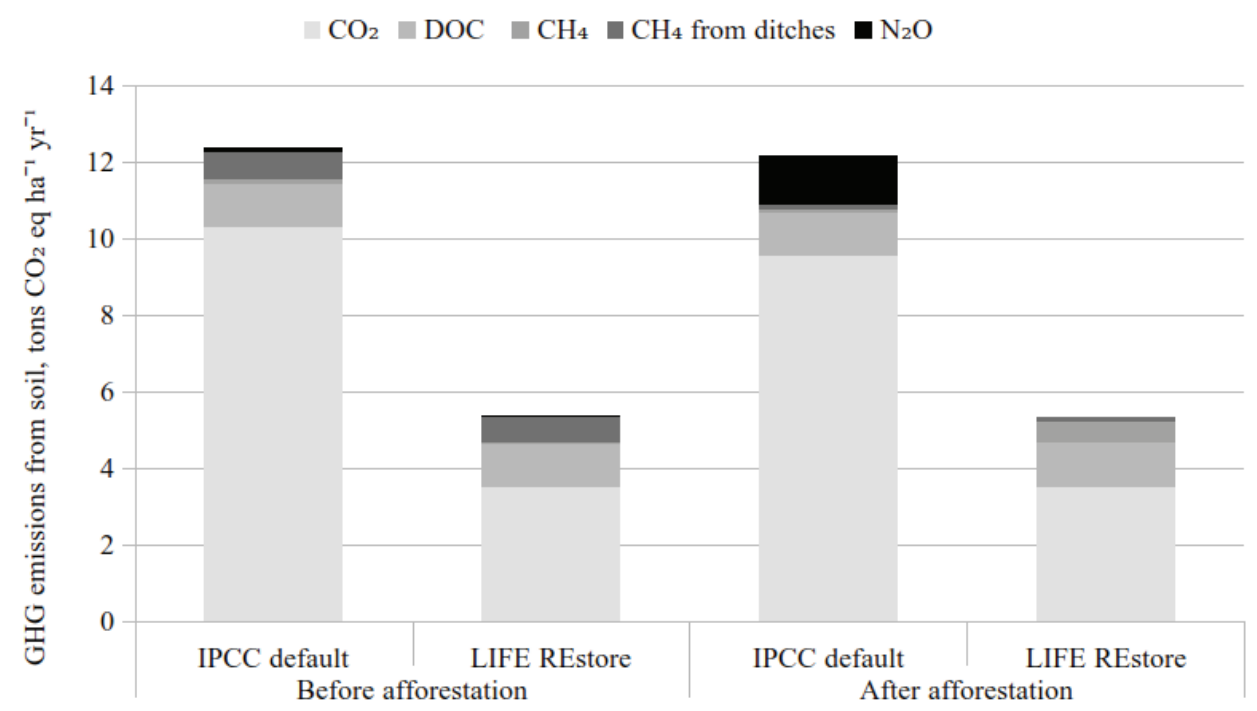

Figure 1. The average annual GHG emissions from soil in afforested area and abandoned peatland. 


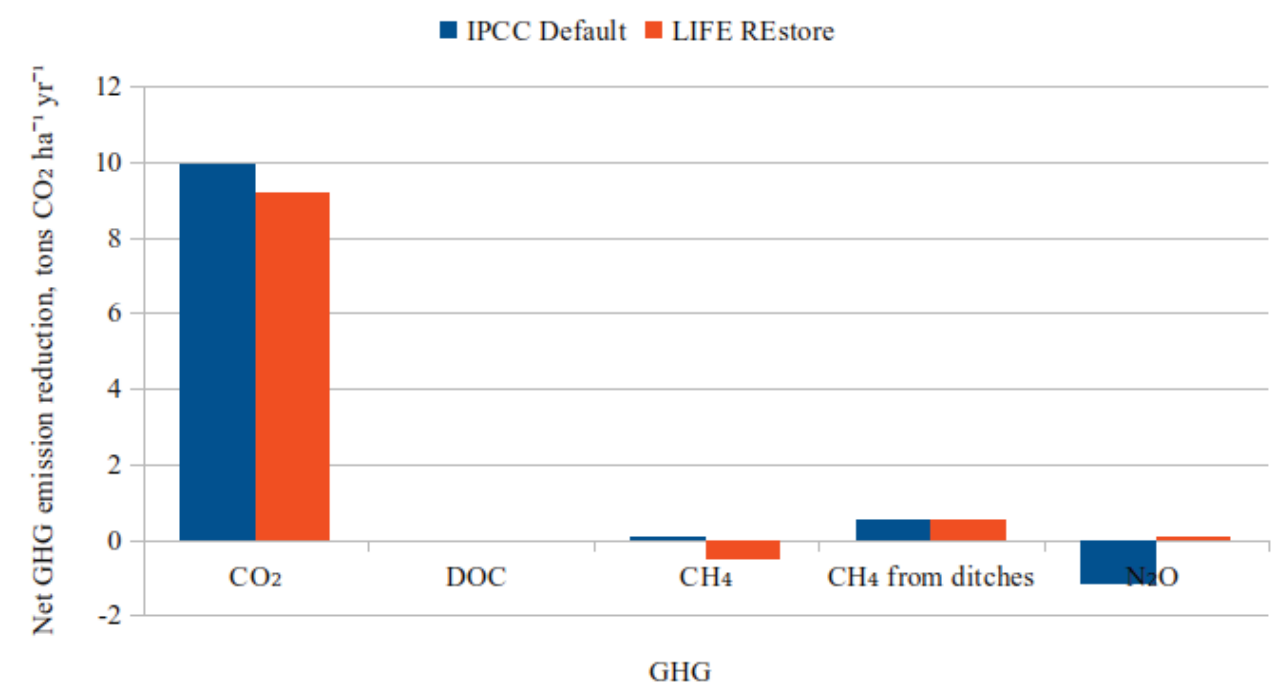

Figure 2. The average annual GHG emission reduction due to afforestation in a 30-year period.

\section{Conclusions}

Afforestation of degraded peatlands can contribute to significant GHG reduction in wetlands - up to $20 \%$ of the net GHG emissions due to wetlands management. The most of the GHG mitigation potential is ensured by accumulation of $\mathrm{CO}_{2}$ in living biomass.

Despite the fact that the elaborated emission factors are within the range of uncertainty of the default emission factors provided in the IPCC 2014 Wetlands supplement, application of country specific emission factors is important. They increase accuracy and turn the net increase of GHG emissions from soil due to afforestation, if the default emission factors by the Wetlands supplement are applied, into net removals, if the country specific factors are applied.
Increase of accuracy of the emission factors is also important, because the value and sign of different GHGs is changing $-\mathrm{CH}_{4}$ turns into net source of emissions and value of $\mathrm{N}_{2} \mathrm{O}$ and $\mathrm{CO}_{2}$ reduces, which points to the conclusion that the default emission factors reflect different conditions (water regime, soil fertility) in comparison to Latvia.

\section{Acknowledgements}

The study was supported by the grant of project of Latvia University of Life Sciences and Technologies 'Implementation of LLU research programme' and the project "Demonstration of climate change mitigation potential of nutrients rich organic soils in Baltic States and Finland LIFE OrgBalt" LIFE18 CCM/LV/001158.

\section{References}

Alm, J., Narasinha, J.S., Minkkinen, K., Lasse, A., Hytönen, J., Laurila, T., Lohila, A., Maljanen, M., Martikainen, P.J., Penttilä, T., Mäkiranta, P., Saarnio, S., Silvan, N., Tuittila, E.S., \& Laine, J. (2007). Emission factors and their uncertainty for the exchange of $\mathrm{CO}_{2}, \mathrm{CH}_{4}$ and $\mathrm{N}_{2} \mathrm{O}$ in Finnish managed peatlands. Boreal Environment Research. 12, 191-209.

Bāders, E. (2011). Akumulētā oglekḷa daudzums dažādās izmantošanas kūdrājos (Amount of accumulated carbon in peatlands of different use). G̦eogrāfija. Ģeologija. Vides zinātne. Referātu tēzes. Rīga: Latvijas Universitāte, 43.-45. lpp. (in Latvian).

Bebre, I., \& Lazdiņa, D. (2017). Izstrādātas kūdras atradnes apmežošanas rezultāti desmit gadus pēc rekultivācijas (Afforestation results in peat extraction sites ten years after reclamation). In Konferences "Kūdra un sapropelis - ražošanas, zinātnes un vides sinerğija resursu efektīvas izmantošanas kontekstāa” rakstu krājums. Kḷaviņš, M. (red.). Rīga: Latvijas Universitāte, 16.-22. lpp. (in Latvian).

Beijere, G., Defais, M., Fišers, M., Flešers, Dž., de Menks, Ē., de Jēgers, F., van Raijets, K., Vandevēge, K., \& Veinendāls, K. (2006). Samaziniet klimata izmaiņas: lietojiet koksni! (Reduce climate change: use wood!). Rīga: Biedrība "Zaḷās mājas". (in Latvian).

Cabinet of Ministers. (2012). Ministru kabineta noteikumi Nr. 570, Derīgo izrakteņu ieguves kārtība (Cabinet Regulation No. 570, Procedures of mining). Latvijas Vēstnesis, 134, 24.08.2012. Cabinet of ministers. Retrieved January 10, 2021, from https://ikumi.lv/ta/id/251021-derigo-izraktenu-ieguves-kartiba. (in Latvian).

Cabinet of Ministers. (2020). Ministru kabineta rīkojums Nr. 696, Par Küdras ilgtspējīgas izmantošanas pamatnostādnēm 2020.-2030. gadam (Cabinet Regulation No. 696, Guidelines for the Sustainable Use of 
Peat 2020-2030). Latvijas Vēstnesis, 231, 30.11.2020. Cabinet of ministers. Retrieved January 12, 2021, from https://likumi.lv/ta/id/319013-par-kudras-ilgtspejigas-izmantosanas-pamatnostadnem-20202030gadam. (in Latvian).

Cools, N., \& de Vos, R. (eds.) (2010). Part X: sampling and analysis of soil. Manual on methods and criteria for harmonized sampling, assessment, monitoring and analysis of the effects of air pollution on forests. Hamburg: UNECE ICP Forests Programme Coordinating Centre.

Drösler, M., Freibauer, A., Christensen, T.R., \& Friborg, T. (2008). Observations and Status of Peatland Greenhouse Gas Emissions in Europe. The Continental-Scale Greenhouse Gas Balance of Europe. 203, 243-261. DOI: 10.1007/978-0-387-76570-9_12.

Hutchinson, G.L., \& Livingston, G.P. (1993). Use of chamber systems to measure trace gas fluxes. Agricultural Ecosystem Effects on Trace Gases and Global Climate Change. 55, 63-78. DOI: 10.2134/asaspecpub55. c4.

Indriksons, A., \& Palejs, M. (2005). Dabas vērtību ilgtspējīga uzturēšana un jaunu atjaunošana (Sustainable maintenance and restoration of new natural values). In Ceḷvedis Latvijas privāto mežu īpašniekiem. Ošlejs, J (Eds.), (pp. 189-196). Rīga: Et cetera. (in Latvian).

Jansons, A. (2016). Latvijas kūdras atradņu datu kvalitātes ieteikumu sagatavošana to uzlabošanai un izmantošanai valsts stratēǵijas pamatdokumentu sagatavošanā (Preparation of quality recommendations of Latvian peat deposits for improvement and use in preparation of national strategy frameworks). Rīga: Biedrība 'homo ecos'. (in Latvian).

Kḷaviņš, M., \& Zaļoksnis, J. (Eds.). (2016). Klimats un ilgtspējīga attīstība (Climate and Sustainable development). Rīga: LU Akadēmiskais apgāds. (in Latvian).

Kløve, B., Berglund, K., Berglund, Ö., Weldon, S., \& Maljanen, M. (2017). Future options for cultivated Nordic peat soils: Can land management and rewetting control greenhouse gas emissions? Environmental Science \& Policy. 69, 85-93. DOI: 10.1016/j.envsci.2016.12.017.

Lazdiņš, A. (2015). Mežsaimniecisko darbību ietekme uz siltumnīcefekta gāzu emisijām un $\mathrm{CO}_{2}$ piesaisti (Impacts of forestry activities on greenhouse gas emissions and $\mathrm{CO}_{2}$ sequestration). Pārskats par AS 'Latvijas Valsts meži’ pasūtītā pētījuma darba uzdevumu izpildi. Salaspils: Latvijas Valsts mežzinātnes institūts 'Silava'. (in Latvian).

Liepiņš, J., Baders, E., \& Liepa, J. (2009). Izstrādāto kūdras atradņu mākslīgās apmežošanas rezultāti Olaines mežniecībā (Results of artificial afforestation of peat extraction sites in Olaines forestry sector). Ģeogrāfija. Ģeologiija. Vides zinātne: Referātu tēzes. Rīga: Latvijas Universitāte, 86-88. 1pp. (in Latvian).

Makovskis, K., Lazdina, D., \& Popluga, D. (2019). Cut-away peatland re-cultivation with fast growing woody plantations: cost-benefit analysis. In Proceedings of the $9^{\text {th }}$ International Scientific Conference Rural Development 2019, 26-28 September 2019 (pp. 305-312). Lithuania: Vytautas Magnus University Agriculture Academy. DOI: 10.15544/RD.2019.077.

Mhkiranta, P., Hytönen, J., Aro, L., Maljanen, M., Pihlatie, M., Potila, H., Shurpali, N.J., Laine, J., Lohila, A., Martikainen, P.J., \& Minkkinen, K. (2007). Soil greenhouse gas emissions from afforested organic soil croplands and cutaway peatlands. Boreal Environment Research. 12(2), 159-175.

Ministry of Environmental Protection and Regional Development Republic of Latvia. (2017). Progress report under EU Decision 529/2013/EU Article 10. Riga.

Neumann, M., Godbold, D., Hirano, Y., \& Finér, L. (2019). Improving models of fine root carbon stocks and fluxes in European forests. Journal of Ecology. 108(2), 496-514. DOI: 10.1111/1365-2745.13328.

Pingoud, K., Perälä, A.L., Soimakallio, S., \& Pussinen, A. (2003). Greenhouse gas impacts of harvested wood products. Evaluation and development of methods. VTT Research Notes 2189.

Pitman, R., Bastrup-Birk, A., Breda, N., \& Rautio, P. (2010). Part XIII: Sampling and analysis of litterfall. In: Manual on methods and criteria for harmonized sampling, assessment, monitoring and analysis of the effects of air pollution on forests, 16. Hamburg: UNECE ICP Forests Programme Co-ordinating Centre.

Priede, A., \& Gancone, A. (eds.). (2019). Sustainable and responsible after-use of peat extraction areas. Riga: Baltijas krasti.

Salm, J.-O., Maddison, M., Tammik, S., Soosaar, K., Truu, J., \& Mander, Ü. (2012). Emissions of $\mathrm{CO}_{2}, \mathrm{CH}_{4}$ and $\mathrm{N}_{2} \mathrm{O}$ from Undisturbed, Drained and Mined Peatlands in Estonia. Hydrobiologia. 692(1), 41-55. DOI: 10.1007/s10750-011-0934-7.

Sathre, R., \& O’Connor, J. (2010). Meta-analysis of greenhouse gas displacement factors of wood product substitution. Environmental Science \& Policy. 13(2), 104-114. DOI: 10.1016/j.envsci.2009.12.005.

Skrebele, A., Rubene, L., Lupkina, L., Cakars, I., Siṇics, L., Lazdāne-Mihalko, J., Puḷke, A., Klāvs, G., Gračkova, L., Lazdiņš, A., Butlers, A., Bārdule, A., Lupiķis, A., Līcīte, I., Bērziņa, L., Gancone, A., \& Zustenieks, G. 
(2020). Latvia's National Inventory Report: Sumbission under UNFCCC and the Kyoto Protocol. Rīga: Ministry of Environmental Protection and Regional Development of the Republic of Latvia.

Zālītis, P. (2006). Mežkopības priekšnosacījumi (Forestry preconditions). Rīga: Et cetera. (in Latvian).

Quinty, F., \& Rochefort, L. (2003) Peatland Restoration Guide. $2^{\text {nd }}$ edition. Canada: Canadian Sphagnum Peat Moss Association and New Brunswick Department of Natural Resources and Energy.

XQX AG. (2011). ICP Forests. Retrieved January 10, 2021, from http://icp-forests.net/. 